Mukaddime, 2019, 10(2), 597-618

DOI: $10.19059 /$ mukaddime.603370

\title{
Azaltarak Çoğaltmak: Hüseyin Cöntürk Ve Hayriye Ünal’ın Hipertext Uygulamaları
}

Gökhan Tunç

Öz:Iyi bir şiirin kelimelerinin yerinin değiştirilip değiştirilemeyeceği ya da iyi bir şiirden kelime çıkarılıp çıkarılamayacağı konusu edebiyat tarihinde tartışılan bir konu olagelmiştir. Yahya Kemal Beyatlı, Ahmet Haşim, Ahmet Hamdi Tanpınar ve Behçet Necatigil gibi isimler şiirin bütünlüğüne atıfta bulunarak tamamlanmış iyi bir şiire en ufak bir müdahalede bulunmanın mümkün olmadığını ileri sürerler. Onlara göre bir sözcüğün yeri değiştirildiğinde bile şiir iyi olma özelliğini kaybeder. Buna karşlık Türk edebiyat tarihinde bir şairin başka şairlerin şiirlerine yaptığı müdahalelerle de sıklıkla karşılaşılabilmektedir. Öyle ki Yahya Kemal ve Behçet Necatigil gibi iyi bir şiire müdahale edilemeyeceğini düşünen şairler, başka şairlerin şiirlerini düzeltme gayreti içine girmişlerdir. Söz konusu çabanın altında yatan neden bazen müdahalede bulunduğu şair üzerinde şiirsel hâkimiyet kurmak bazen de dostça önerilerde bulunmak olabilir. Bu makalede iki örnek üzerinden Türk şiirinde başka şairlerin şiirlerine yapılan müdahaleler sorunsallaştırılacaktır. Bahsedilen örnekler Hüseyin Cöntürk'ün, Edip Cansever'in "Salıncak”; Hayriye Ünal'ın, Cahit Zarifoğlu'nun "Başım Eğik Dilim Kapalı Gözler Kançanağı Anlamında" şiirine yaptıkları müdahalelerdir. Her iki edebiyatçı da benzer yöntemler izleyerek ele aldıkları şiirlerdeki bazı sözcüklerin üzerini çizerler ve geriye kalan sözcüklerle yeni bir şiir oluştururlar. Ancak Cöntürk ve Ünal, konu edindikleri şiirlerdeki sözcükleri eksiltip yeniden yazarlarken farklı amaçlar ortaya koyarlar. Cöntürk, eleştiri anlayışını Cansever'in şiiri üzerinde somutlar; Ünal ise Zarifoğlu'nun şiiri üzerinden estetik bir meydan okumaya girişir. Makalede, Cansever ve Zarifoğlu'nun şiirleri, “hipotext”; Cöntürk ve Ünal'ın bu şiirlerdeki sözcüklerin üzerini çizerek oluşturdukları yeni şiir, "hipertext”; her iki

\footnotetext{
${ }^{1}$ Doç. Dr., Anadolu Üniversitesi, Açıköğretim Fakültesi / Türk Dili ve Edebiyatı Bölümü/ Yeni Türk Edebiyatı Anabilim Dalı, gokhantunc@anadolu.edu.tr,ORCID No: https://orcid.org/0000-0002-9450-8045.
} 
metnin birlikte aynı mekânda yer alması ve birbirleriyle kurdukları ilișkiler "palimpsest" kavramıyla anlamlandırılacaktır.

Anahtar kelimeler: şiir, şair, palimpsest, hipotext, hipertext.

\title{
Increasing By Decreasing: Hüseyin Cöntürk And Hayriye Ünal's Hypertext Practices
}

\begin{abstract}
Whether to change the places of words in a good poem, or to omit words from it or not has been debated throughout the history of literature. By referring to the unity of poetry, names such as Yahya Kemal Beyatlı, Ahmet Haşim, Ahmet Hamdi Tanpınar and Behçet Necatigil put forward that it is impossible to change any little part of a good, complete poem. According to them, a poem loses its value as a good one when the place of only one word is changed. On the other hand, the history of Turkish literature has frequently seen the cases when a poet changes poems by other poets. In fact, poets such as Yahya Kemal and Behçet Necatigil who think that it is impossible to change a poem have tried to correct poems by others. The reason behind this effort can sometimes be either to gain a poetical dominance over the other poet or to give some friendly advice. In this article, the changes done in poems by other poets in Turkish poetry are going to be problematise through two examples. The examples mentioned are the changes done by Hüseyin Cöntürk in Edip Cansever's 'Swing' and by Hayriye Ünal in Cahit Zarifoğlu's 'In the Meaning of Head Down Mouth Closed Eyes Bloodshot' poems. Both of the poets create new poems out of the ones in hand by omitting some words and combining the rest with similar techniques. Nevertheless, Cöntürk and Ünal put forward different aims while rewriting these poems by reducing them. While Cöntürk makes his criticism perception concrete on Cansever's poem, Ünal embarks on an esthetical challenge through Zarifoğlu's poem. In the article, Cansever and Zarifoğlu's poems will be named as hypotext, Cöntürk and Ünal's new poems created by omitting the words in the aforementioned poems will be called as hypertext, and the cases in which both of the texts are in the same place and the relationship between them will be named as palimpsest.
\end{abstract}

Keywords: poem, poet, palimpsest, hypotext, hypertext 


\section{Giriş}

Türk edebiyatında bilhassa Yahya Kemal Beyatlı ve Necip Fazıl Kısakürek gibi şairlerin kendi şiirleri üzerinde sık sık değişiklik yaptıkları bilinmektedir. Bu ve benzeri şairler, şiirlerinde değişiklikler yaparak en doğru ve yetkin ifadeye ulaşmayı hedeflemektedirler. Bu nedenle şairlerin şiirlerindeki arayışları onların mükemmeliyetçi kişiliği ile ilişkilendirilmektedir. Ancak Türk edebiyat tarihinde şairlerin kendi şiirlerinde yaptıkları değişikliklerin yanı sıra başka şairlerin şiirlerinde gerçekleştirdikleri müdahaleler de gözlemlenmektedir. Bu makalede temel olarak iki örneklem üzerinden bu durum sorgulanacaktır. Bu doğrultuda ilk olarak özellikle saf şiir poetikasını benimsemiş şairler üzerinden şiirde kelimelerin yerini değiştirmenin ya da şiirden kelime çıkarmanın mümkün olup olmadığı sorusu tartışma konusu yapılacaktır. ifade edilen çerçevede saf şiir anlayışına sahip şairlerin şiirin bütünlüğüne ve şiire yapılacak en ufak müdahale sonucunda onun büyüsünü ve niteliğini kaybedeceği yönündeki inanışlarına vurgu yapılacaktır. Makalede daha sonra iki farklı örneklem üzerinden sanatçıların başka şairlerin şiirlerine müdahalelerinin ne anlama geldiği sorunsallaştırılacaktır. Buna göre bir şairin diğer şair üzerinde şiirsel otoritesini kanıtlamak veya ona poetik önerilerde bulunmak için şiirlerinde değişiklik yaptığı öne sürülecektir. Bunun yanı sıra bir kavramsal çerçeve dâhilinde eleştirmen ya da şairin bir başkasının şiiri üzerinde değişiklik yapması konusunda Türk edebiyatında iki dikkat çekici örnek bulunduğu ifade edilecektir. Bunlar, eleştirmen Hüseyin Cöntürk ve şair Hayriye Ünal'dır. Her ikisi de hipertext başlığı altında başkasına ait şiirlerde değişiklik yaparlar. Bu kapsamda ele aldıkları şiirlerdeki sözcüklerin bir kısmının üstünü çizip bunları çıkararak yeni bir şiir meydana getirirler. Makalede Cöntürk ve Ünal'ın yaptığı bu deneysel girişimin ne anlama geldiği, yaptıkları hipertextlerin onların şair ya da eleştirmen kimlikleri ile ilişkisi, hipotextlerle kurdukları ilişkilerin niteliği gibi konular tartışılacaktır. Bu çerçevede öncelikle palimpsest, hipotext ve hipertext kavramlarıla gönderimde bulunulan anlam verilecek, daha sonra Cöntürk ve Ünal'ın deneysel yazma girişimleri bu kavramlar merkezinde tartışılacaktır.

\section{Şiirde Kelimelerin Yerini Değiştirmek ya da Şiirden Kelime Çıkarmak Mümkün mü?}

Fransız Akademisi üyesi Henri Bremond, Poésie Pure (Saf Şiir) adlı eseriyle Yahya Kemal Beyatlı, Ahmet Haşim ve Ahmet Hamdi Tanpınar gibi modern Türk şiirinin birçok önemli şairini etkileyen görüşler ileri sürer. Bremond'a göre mısralardaki sözcüklerin başarıyla sıralanışı ritim denilen "âhenk dalgalanmasını" yaratır ve bu yüzden de mısralardaki sözcükler yerlerinden oynatılamaz (Uysal, 2009: 135). Bremond'la koşut olarak Yahya Kemal, Edebiyata Dair adlı kitabında, nitelikli bir şiirin tamamlandıktan sonra ondan kelime eksiltmenin ya da onun kelimelerinin yerini değiştirmenin mümkün olup olamayacağına dair önemli bir sorgulama yapar. Yahya Kemal, Edebiyata Dair'de yer alan "Şiir Okumaya Dâir” başlıklı yazısında Nedim'in “Dökülen mey kırılan 
şişe-i rindân olsun" mısrası üzerinden poetikasını açımlar ve bu süreçte mısra kuruluşuyla ilgili dikkat çekici ifadelerde bulunur. Ona göre Nedim, şiddetli bir şevki ifade etmek için altı kelimeyi "muayyen bir istifle" bir araya getirmiştir. Her kelime o şevk anını açığa çıkaran bir tınnettedir ve böylelikle her bir kelime o mısranın musikisini oluşturur:

Bu mısrâda altı kelime vardır. Bu altı kelimeyi şâir deruni âhenk kudretiyle muayyen bir istifle tecelli ettirmiştir. Bu kelimelerin hiçbiri yerinden oynayamaz. Bu kelimelerin hiçbiri fazla veyâhut eksik değildir. Altısı birden bir mûsıkî cümlesi teşkil etmektedirler. Baştaki dökülen bin türlü mânâda kullandığımız dökülen değildir. Nedîm'in tam o şevk ânını ifâde ettiği bir tınnettedir. (Beyatlı, 1997: 4)

Alıntıda da görüldüğü gibi Yahya Kemal kelimeleri notalara benzetir ve ona göre nasıl ki bestede herhangi bir notanın yerini değiștirmek mümkün değilse mısralarda da kelimelerin yerini değiștirmek veya onları eksiltmek söz konusu olamaz. Bu şekilde kelimeler konusunda hiçbir tasarrufta bulunulamayan şiirlerle ilgili Yahya Kemal "hâlis şiir" tabirini kullanır. "Hâlis şiir"in temel vasfı ise "mukadder ve değişmez bir terkip" (1997: 5) olmasıdır. Yahya Kemal'in kendi şiirlerinde varmaya çalıştığı nokta, tam da "hâlis şiir"le gönderimde bulunduğu anlamdır. $O$, şiirdeki bütün kelimelerin belirli işlevle bir araya geldiği bütüncül ve parçalanamaz yapılar hayal eder. Kelimelerden herhangi birinin çıkarılması, söz konusu yapının çökmesine neden olacaktır. Yahya Kemal'in şiirlerini yayımlamadan önce defalarca silip tekrar yazması, değiştirilemez yapıya kavuşma hayaliyle ilişkilidir.

Yaşadığı dönemde Yahya Kemal'in büyük rakibi olan Ahmet Haşim, her ne kadar Yahya Kemal kadar doğrudan ifade etmese de, şiir üzerinde yapılacak her türlü müdahaleye karşı çıkar. Ona göre şiir sessiz bir şarkıdır. Bu şarkıyı oluşturacak kelimeler anlamlarına göre değil, cümledeki telaffuz kıymetine göre seçilmelidir. Şairin hedefi, her kelimenin cümledeki mevkisini, elde edilmek istenen sese göre belirlemektir. Bu çerçevede bir kelimenin diğer kelimelerle olacak temas ve çarpışmasından, esrarengiz izdivaçlarından tatlı, mahrem ya da havai bir ses elde edilir (1999: 71-72). Dolayısılla kelimelerin cümledeki mevkisini değiştirmek mümkün değildir. Aksi durumda Ahmet Haşim'in metaforuyla ifade edecek olursak, elektrik cereyanı türünden olan şiirsel akış kesintiye uğrayacaktır (1999: 71). Nitekim bu şiirsel akış son bulunca şiir de yok olacaktır.

Ahmet Haşim'in tamamlanmış bir şiirde kelimelerin yerinin değiştirilemeyeceğine veya kelimelerin eksiltilemeyeceğine yönelik dolaylı ifadelerini yine Ahmet Haşim üzerinden çok daha net ifade eden kişi Sabahattin Eyuboğlu olmuştur. Eyuboğlu, "Öz Şiir” adlı yazısında Ahmet Haşim'in üslubunu takip ederek ve onun bir mısrasını örnek vererek şiirde "basit cüzler" arasında "bediî vahdeti" temin eden "başka bir şey" olduğundan söz eder. Eyuboğlu, bediî vahdeti teşkil eden "başka bir şey"le ne kastettiğini açımlama gereği duymaz, ancak bediî vahdetle ilgili söylediği sözler dikkat çekicidir. Ona göre şiir 
öyle bir bütündür ki "onu en küçük bir iklim değişikliği, en hafif bir temas öldürebiliyor."dur (1981: 10). Eyuboğlu, düşüncelerini Ahmet Haşim'in "Merdiven" şiirinin ilk mısrası üzerinden somutlamaya çalışır. "Ağır ağır çıkacaksın bu merdivenlerden"2 mısrasını değiștirerek "Bu merdivenlerden ağır ağır çıkacaksın." şeklinde yazar, bu şekilde sihrin kaybolduğunu vurgular. Ona göre mısradaki bu değişiklikle beraber "Ortada artık bir posadan, boş bir esans şişesinden başka bir şey yok”tur (1981: 11). Eyuboğlu'nun sihrin kaybolduğu yönündeki sözleri Ahmet Haşim'in "sihirkâr” tesiriyle koşut niteliktedir.

Daha önce belirtildiği gibi Yahya Kemal ve Ahmet Haşim'in benzer görüşler ileri sürmesinde, poetikalarını oluşturdukları ortak kaynaklar etkili olmuştur. Söz konusu ortak kaynakların başında ise "saf şiir" gelmektedir. Şiirin özerkliğini ve şiirde musikiyi ön plana alan bu poetik çizgide, kelimelerin seçimi ve cümledeki mevkileri önem kazanır. Aynı poetik tavır Stéphane Mallermé'nin "şiir fikirlerle değil, kelimelerle yazııır." düşüncesinde de görülebilir (Tanpınar, 1995: 29). Buna göre şiir, fikirleri aktarmak için bir araç değildir, aksine özerk bir anlama sahiptir. Bu şiirde kelimelerin işlevi ve önemi artmış, hangi kelimelerin seçildiği ve başka hangi kelimelerle yan yana geldiği büyük bir ehemmiyet arz etmiştir.

Saf şiir anlayışını sürdüren Ahmet Hamdi Tanpınar, Yahya Kemal ve Ahmet Haşim'e eklemlenen bir poetik görüşe sahiptir. Genelde sanatı özelde ise şiiri "her şeyden evvel bir zanaatkârlık" olarak gören Tanpınar, dili şekil vereceği bir maddeye benzetir (1997: 143). Ayrıca Tanpınar, Mallermé'ye atıfta bulunarak mısrayı "birçok kelimelerden teşekkül etmiş, büyük ve hususî bir dalgalanma olan tek bir kelime" diye tarif eder (2000: 352). Tek bir kelime metaforu, bu makalenin konusunu doğrudan ilgilendiren, şiirde kelimelerin yerinin değiştirilemeyeceği ve şiirden kelime çıkarılamayacağı savıyla ilgilidir. Bununla birlikte Tanpınar'ın söz konusu düşüncesi, daha önce değinilen "bediî vahdet”le aynı anlama gönderimde bulunur.

Bahsedilen isimlerin yanı sıra saf şiir anlayışını sürdüren Necip Fazıl Kısakürek, Ahmet Muhip Dıranas, Cahit Sıtkı Tarancı gibi isimleri de benzer poetik çabanın içinde alımlayabiliriz. Bilhassa Kısakürek'in şiirleri üzerinde yaptığı değişiklikler Yahya Kemal'i hatırlatır ${ }^{3}$. Kısakürek söz konusu müdahaleleriyle şiirlerinde en ufak değişikliğe yer bırakmayacak en kusursuz söyleyişe ulaşmayı hedefler.

Modern Türk edebiyatında şiirde kelime müdahaleleriyle ilgili poetik görüşlere yer veren önemli figürlerden biri Behçet Necatigil'dir. Şiiri söylemekten ziyade susma işi olarak gören Tanpınar'la (2000: 352) koşut olarak sanatın ekleme değil çıkarma olduğunu günden güne daha iyi anladığını dile getirir

\footnotetext{
2 Eyuboğlu'nun kitabında mısradaki “çıkacaksın”, matbu hatayla "ineceksin” şeklinde yazılmıştır. Bk. Eyuboğlu, Sabahattin (1981). Sanat Üzerine Denemeler ve Eleștiriler. İstanbul: Cem, s, 10.

${ }^{3}$ Kısakürek'in şiirlerine müdahaleleriyle ilgili bk. Kavaz, İbrahim (1989). “Necip Fazıl Kısakürek'in Şiiri ve Şiirlerindeki Değişmeler Üzerine”. Fırat Üniversitesi Sosyal Bilimler Dergisi 3 (2): 201-223.
} 
(Necatigil, 2012: 74). Böylelikle her iki şair şiirlerinde çıkarmaya yer bırakmayacak kadar az sözcük kullanılması gerektiğini beyan ederler. Bununla birlikte Necatigil, şiirin bütünlüklü yapısına da dikkat çeker. Ona göre "Şiirin iç yapısı sözcüklerin dağıtım düzeninden, sözcüklerin sıralanışından, onların simetrik ve paralel konumlarından oluşur. Günümüz şairlerinin pek önem vermedikleri iç yapı, ayrıntılı ve çapraşık çatılar toplamıdır." (Necatigil, 2012: 53). Şair, sözcüklerin düzenini, birbirleriyle olan konumunu, sıralanışını göz önünde bulundurarak parçalanmaz bir iç yapı meydana getirir. Bu yapıya herhangi bir müdahale, onun sona ermesine neden olacaktır.

\section{Başka Şairlerin Şiirlerine Yapılan Müdahaleler}

Modern Türk şiirinde bir şairin başka şairlerin şiirleri üzerinde yaptığı müdahalelere dair birçok örnekle karşılaşmak mümkündür. Ancak bu makale kapsamında işlevsel bir öneme sahip özellikle iki örnek burada göz önünde bulundurulacaktır. Söz konusu örneklem Yahya Kemal Beyatlı ve Behçet Necatigil'in başka şair ya da şairlerin şiirleri üzerindeki müdahaleleridir. İlk olarak Yahya Kemal'in bu yöndeki uygulamaları incelenebilir.

"Halis şiir”in sözcükleri üzerinde hiçbir şekilde bir tasarrufta ve müdahalede bulunulamayacağını düşünen Yahya Kemal'in bilhassa rakip gördüğü şairlerin şiirleri üzerinde değişiklikler yapması dikkat çekicidir. Bu şekilde "halis şiir” yazmadıklarını kanıtlamaya çalıştığı isimler arasında Abdülhak Hâmid Tarhan, Tevfik Fikret, Mehmet Akif Ersoy ve Ahmet Haşim gibi modern Türk şiirinin önde gelen isimleri bulunmaktadır. Yahya Kemal, adı geçen isimlerin şiirlerini yeniden düzenleyerek onlardan daha başarılı bir şair olduğunu kanıtlamak ister. Örneğin "şair-i azam” olarak anılan Hâmid'in Makber'de yer alan

Bir gün dedi ızdırap içinde

Ben ölmeğe gelmişim bu Hind'e

Ölmek dedi kahkahayla güldüm

Duydum ki fakat içimden öldüm.

mısralarını ele alır ve son mısrasının "Güldüm, fakat ah!... İçimden öldüm..." şeklinde yazmasının daha güzel olacağını iddia eder. Lisan vurgusunu burada ön planda tutar (Ayda, 1962: 26). Dolayısıyla Yahya Kemal, Hâmid'in şiirinde mantık hataları arar ve şiirlerde düzeltmeler yapar.

Yahya Kemal'in şiirlerini hedef aldığı bir diğer isim, Servet-i Fünun'un lideri kabul edilen Tevfik Fikret'tir. Onun birçok şiiri üzerinde müdahalelerde bulunur Yahya Kemal. Örneğin Fikret'in “Ken'an evine yâreli dönmüş geliyordu.” mısrasını "Ken'an yaralanmış eve yorgun geliyordu." şeklinde söylemenin Türkçe söyleyiş bakımından daha doğru olduğunu öne sürer (Uysal, 2009: 139). Ancak Yahya Kemal'in esas hesaplaştığı ismin Ahmet Haşim olduğu söylenmelidir. 
Sermet Sami Uysal, Yahya Kemal'in bahsedilen tavrının arkasında, bazı kişilerin Haşim'i ondan daha büyük şair olarak görmelerinin yattığını ileri sürer (2009: 143). Bu anlamda Yahya Kemal'in, Haşim'in sevilen şiirlerinden biri olan "Mukaddime" şiirini neredeyse kelime kelime eleştirmesi dikkat çekicidir. Haşim'in şiirinin ilk bölümü şöyledir:

Zannetme ki güldür, ne de lâle,

Âteş doludur, tutma yanarsın

Karşında şu gülgûn piyâle... (1999: 85)

Haşim’i özellikle Türkçe söyleyiş konusunda eleştiren Yahya Kemal ilk mısranın "Zannetme ne güldür ne de lâle" olması gerektiğini öne sürer. Yine "âteş" kelimesini imale ile söylenememesinin yanı sıra ateşi tutmanın mantıklı olmadığını söyler. Gülgûn yerine gül renkli demenin Türkçe söyleyiş açısından daha doğru olduğunu dile getirir (Uysal, 1959: 139).

Yahya Kemal'in bahsedilen şiirsel müdahalelerinin rakiplerini alaşağı etme, rakipleri üzerinde tahakküm ve şiirsel otorite kurma, onlardan daha iyi bir şair olduğunu kanıtlama anlamı taşıdığı ileri sürülebilir. Böylelikle Yahya Kemal, yaşadığı çağın en önemli şairi olduğunu kanıtlama çabasındadır. Öte yandan Türkçe söyleyiş konusu, onun rakipleri karşısında üstünlük kurma gayretinde önemli bir yer edinmektedir.

Behçet Necatigil'in şiirsel müdahaleleri konusunda dikkat çekici olan örnek, Edip Cansever'e yazdığı mektupta ortaya çıkar. Necatigil, Cansever'in Sevda ile Sevgi kitabı dolayısıyla ona görüşlerini içeren bir mektup yazar. Cansever'e kendisini yadırgatan bir iki nokta üzerinde duracağını söyleyen Necatigil, Cansever'in sözlerinden alınmaması için önlem alır ve "Hoş karşıla, bağışla!” der (2001: 267). Bu ricadan sonra Necatigil, şiiriyle ilgili önerilerde bulunur. Ona göre Cansever'in şiirinin "Biz isteyelim istemeyelim sürüp gider böylece" mısrası, düzyazı için bile ağır bir bileşimdir. Necatigil, hantal, uzun ve yorucu bulduğu mısrayı şöyle değiștirir: “iste, isteme sürüp gider böylece.” (2001: 267) Necatigil, şiirdeki eksiltmelere devam eder ve şiirin ikinci bölümünün ikinci mısrasındaki "kalmış" sözcüğünün atılması gerektiğini söyler. Çünkü "unutmak” sözcüğünde "kalmamışlık” ifadesinin bulunduğunu düşünür.

Necatigil, Cansever'in şiirinin son bölümünde "bir" kullanımını fazla bulur. Burada üç kez bir kullanılmıştır ve Necatigil bu durumun şiirin aleyhinde bulunduğuna inanır. Yine Necatigil, son mısranın başındaki “bir”in atılmasının mısrada bir kayıp yaratmayacağını öne sürer. Necatigil, mektubunu Cansever'in gönlünü almaya çalışarak bitirir ve söylediklerini ukalalık ve "haddi tecavüz" olarak algılamaması ricasında bulunur. Bu önerileri, dostluklarına güvenerek kendi görüşünü dile getirmek olarak tanımlar (2001: 267).

Yahya Kemal'in rakip şairler üzerinde şiirsel otorite kurma, onlardan daha iyi bir şair olduğunu gösterme çabası, Necatigil'de yerini bir dost önerisine 
bırakır. Necatigil, Cansever'in -kendi poetik anlayışı içerisinde- daha iyi şiir yazmasını ister. Cansever'in şiiri düzyazıya yaklaştıran tavrına karşılık Necatigil onu saf şiir anlayışına yaklaştırma yönünde önerilerde bulunur. Yahya Kemal ve Necatigil arasındaki tavır farklılığının yanı sıra önerilerin içeriği konusunda da temel farklılıklar olduğu söylenmelidir. Yahya Kemal, bilhassa Türkçe söyleyiş konusunda diğer şairleri eleştirir ve onların şiirlerine müdahale eder. Buna karşılık Necatigil'in Cansever'in şiirine müdahalesi sözcük eksiltme odağında gerçekleşir ki; bahsedilen durum bu makalede ele alınacak iki örneğin tavrıla doğrudan ilgilidir. Gerek Hüseyin Cöntürk gerekse Hayriye Ünal, müdahalede bulundukları şiirlerde sözcük eksiltme yoluna girerler. Her ikisinin bu çabasını anlamlandırmak için öncelikle "palimpsest” kavramını yakından incelemek gerekir.

\section{Palimpsest, Hipotext ve Hipertext Kavramları}

Jorge Luis Borges, “Don Quixote Yazarı Pierre Menard” adlı öyküsünde Menard adlı bir kişiden ve onun Don Quixote'nin tıpkı yazımını gerçekleştirme çabasından bahseder. Aslında o, Don Quixote'yi değil kendisini yazmak ister. Menard'ın asıl hedefi Miguel de Cervantes'in özgün eseriyle kelime kelime örtüşecek birkaç sayfa yazabilmektir (Borges, 2014: 71). Borges, böylelikle üst üste yazılmış metinlerden söz etmiş olur ki bu durum akla palimpsest kavramını getirir.

Palimpsest, Grekçe “palin” (tekrar) ile "psestos” (kazınmış) sözcüklerinin birleşmesinden (Yavuz, 2013: 24) oluşur. Palimpsestin sözlük anlamı da kelimenin etimolojisi ile örtüşür. Buna göre özellikle Orta Çağ'da, kâğıt yaygınlaşmadan önce, parşömen ve parşömen benzeri ince nesnelerin hâkim olduğu çağda yaygın bir kullanıma sahip olan palimpsest (Baldick, 2001: 181), üstündeki el yazmasından temizlenerek tekrar tekrar kullanılmış bir parşömen ya da ruloya verilen isimdir (Dillion, 2017: 25). Bir başka şekilde ifade edecek olursak palimpsest, yazılı olan metnin önce bir bölümünü ya da tamamını silip veya kazıyıp üstüne yeni bir yazı yazılan el yazmasıdır (Dillion, 2017: 26).

Sarah Dillion, Palimpsest: Edebiyat, Eleștiri, Kuram adlı kitabında palimpsest kavramının 1845'te Thomas De Quincey'nin “The Palimpsest” başlıklı denemesiyle birlikte metaforlaşma sürecine girdiğini belirtir. Söz konusu kavram 1845'ten sonra mimari, coğrafya, jeoloji, paleontoloji, buzulbilim, astrofizik, biyokimya, genetik, sinirbilim, nörobiyoloji, nörhesaplama ve enformasyon teknolojisi gibi çok farklı alanlarda kullanılır (Dillion, 2017: 13). Tam da bu nedenle palimpsest Dillion'un vurguladığı gibi farklı disiplinlerin karşılaşma alanı olmuştur (Dillion, 2017: 13).

Palimpsestte dikkat çekici olan özellik, ikincil yazının arkasından yüzünü göstermesidir. “ilk yazının hayaletimsi izi, kalan mürekkepteki demirin havadaki oksijenle temas etmesi sonucu ortaya çıkan kırmızımsı kahverengi oksit yüzünden sonraki yüzyıllarda yeniden" (Dillion, 2017: 27) ortaya çıkar. Aynı parşömen üzerinde ilk ve ikinci yazının birlikte bulunması ve ilk yazının ikinci 
yazının ardından görülebilmesi, palimpsestin metinlerarası ilişkinin bir metaforu olarak yorumlanabilmesinin önünü açar. Gérard Genette Palimpsestes adlı kitabında ifade edilen metaforlaşma ile ilgili şunları söyler:

Metinsel ilişkiler alanında nesnenin bu ikiyüzlülüğü eski bir analoji olan palimpsest yoluyla temsil edilebilir: Aynı parşömenin üzerinde bir metin diğerinin üstüne bindirilebilir ve biri diğerini saklamaz, bilakis kendini aradan göstermesine izin verir. (Akt. Dillion, 2017: 120)

Genette ve birçok postmodernist eleştirmen, ilk yazılan yazı ile onun üzerine yazılan yazının aynı yüzeyde bir araya gelmesinden ve birbirleriyle ilişkisinden esinlenerek palimpsest kavramılla metinleri anlamlandırmaya çalışılar. Burada "Ortak kanıya göre, eski bir yazar 'ilk kez' yazmış, ardından başka bir yazar (çoğu zaman bir taklitçi ya da kopyacı diye anılan) yeni bir metnin sayfalarını bir başka türlü yeniden yazmıştır." (Aktulum, 2000: 217). Genette, ilk ve ikinci yazıyla ilgili $A$ ve $B$ metinleri ifadelerini kullanarak aralarındaki ilişkiyi şöyle somutlamaya çalışır:

B metni A metninden bahsedilmesi değil, A olmadan var olamamasıdır, ondan benim muvakkaten dönüşüm adını verdiğim bir süreç yoluyla neşet eder ve sonuç olarak illa ondan bahsetmeden ya da onu iktibas etmeden az çok sezilebilir şekilde onu çağrıştırır. (Akt.

Dillion, 2017: 119)

"Hipotext (hypotexte)", yani "alt metin" ile "hipertext (hypertexte)", yani "ana metin", Genette'nin palimpsest üst başı̆̆ı̆ı ile ele aldığı kavramlardır. Buna göre "Hipotext" alt metin olarak "hipertext"e kaynaklık etmenin yanı sıra onunla karşılıklı ilişki içine girer (Aktulum, 2000: 83). Genette'nin A metniyle kastettiği anlamın hipotexte, $B$ ile gönderimde bulunduğu kavramın hipertexte karşılık geldiği öne sürülebilir. Her iki kavram da palimpsestte bir araya gelir ve karşılıklı ilişki içine girerler. Buna göre palimpsestteki ilk yazı hipotextken ilk yazının kazılması ile oluşturulan ikinci yazı hipertexttir.

Buraya kadar çerçevesi çizilmeye çalışılan palimpsest kavramı, Hüseyin Cöntürk ve Hayriye Ünal'ın metinlerini yorumlamak açısından işlevsel bir önemdedir.

\section{Hüseyin Cöntürk'ün Edip Cansever'in “Salıncak” Șiirini Yeniden Yazımı}

Hüseyin Cöntürk, Edip Cansever'in Yerçekimli Karanfil, Umutsuzlar Parkı ve Petrol gibi şiir kitaplarını eleştirmesine karşılık onun Nerde Antigone kitabında yer alan "Salıncak" şiirinden övgüyle bahseder. Cöntürk'e göre Cansever "Salıncak" şiirinden önce arayan ancak az şey bulan bir şairdir. Ancak Cansever'in yönsüz ruh durumları "Salıncak"la birlikte bir anlam kazanır, dağınık görünümünden çıkıp bir bütün içindeki yerine oturur, sonuç olarak da okura "tam" bir dünya sunar. Ona göre "Salıncak" şiiri eksiksizdir (2006a: 391). Cöntürk yazısının sonunda "Salıncak" şiirinin başarılı olması ile ilgili şunları söyler: 
“'Salıncak'ın başarılı bir şiir oluşunun başkaca bir sebebi de onun sağlam bir iç mantığa dayanmasıdır. Bu matematiksel değil estetik, duygusal bir mantıktır." (Cöntürk, 2006a: 409). Fakat Cöntürk "Salıncak" şiirinin iç mantığına ve “tam”"ığına dair övgüsüne karşılık -kendi ifadesiyle- bu şiiri hipotext olarak kullanıp ona müdahalelerde bulunmaktan kendisini alamaz. Birlikte kitap yazdığı Asım Bezirci'nin Umutsuzlar Parkı şiirinden bazı mısralar çıkarıldığında şiirden bir şey eksilmeyeceğini iddia etmesi (1961: 72-73) ile koşut olarak Cöntürk, "Salıncak" şiirinden sözcükler eksiltir ve bu şiiri “hipotext” olarak kullanır.

Ancak hem literal hem de metaforik olarak palimpsest kavramı Cöntürk'ün edimini anlamlandırmak için işlevsel önemdedir. Papirüste ilk (hipotext) ve ikinci yazı (hipertext) aynı anda bulunur ki burada ilk yazının kazınma ya da silinme durumu bulunmaktadır. Buna karşılık, Cansever'in şiiriyle Cöntürk'ün sözcük çıkarma ediminin aynı sayfada bulunması dikkat çekicidir. Bu özellik, literal anlamda her ikisini birbirine yakınlaştırır. Öte yandan Dillion'un palimpsestvarilik kavramıla ifade ettiği gibi her iki metnin birbiriyle karşılıklı etkileşimi, birbirlerini zenginleştirmeleri tartışma konusu olan uygulamanın palimpsest uygulaması içerisinde değerlendirilmesini mümkün kılar. Cöntürk'ün, Cansever'in "Salıncak" şiiri üzerindeki müdahaleleri şöyledir:

\begin{tabular}{|c|c|c|c|}
\hline 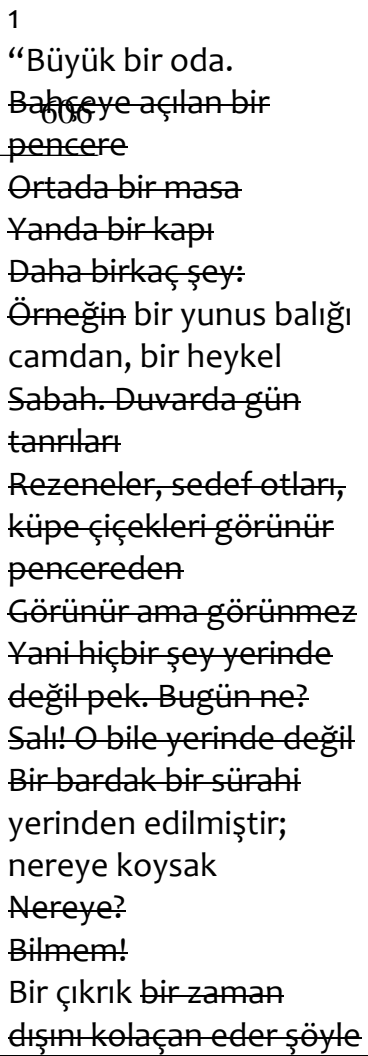 & 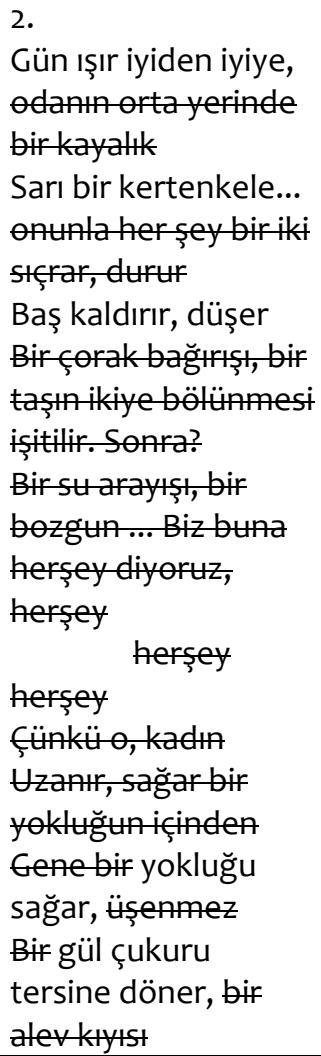 & $\begin{array}{l}\text { 3. } \\
\text { Sonra ne? Sabah! } \\
\text { İyi bir gün başlar } \\
\text { ne de olsa } \\
\text { Tepeden tırnağa } \\
\text { beyazlar } \\
\text { giyinmiştirkadın } \\
\text { Ne var ki bir kadın } \\
\text { gibideğil, bir aşk, } \\
\text { birumut gibideğłl } \\
\text { Bir aralık gibi durur } \\
\text { dünyada } \\
\text { Işte bir soru! } \\
\text { Okurken elinde } \\
\text { tuttuğu; okumaz, } \\
\text { gene elinde } \\
\text { tuttuğu } \\
\text { "Önce hep gece } \\
\text { vardı" diyen bir } \\
\text { kitapla } \\
\text { Biz buna bir } \\
\text { sorununsınırsłz } \\
\text { gerilimi diyoruz } \\
\text { Diyoruz; çünküo, } \\
\text { kadın }\end{array}$ & 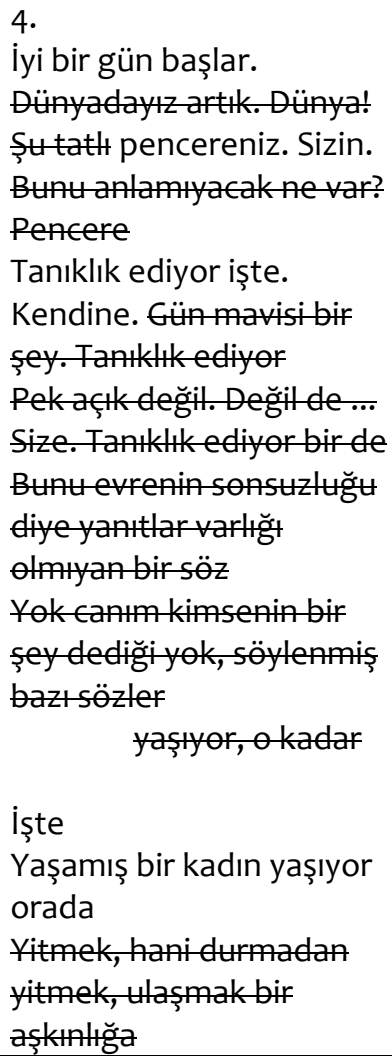 \\
\hline
\end{tabular}




\begin{tabular}{|c|c|c|c|}
\hline 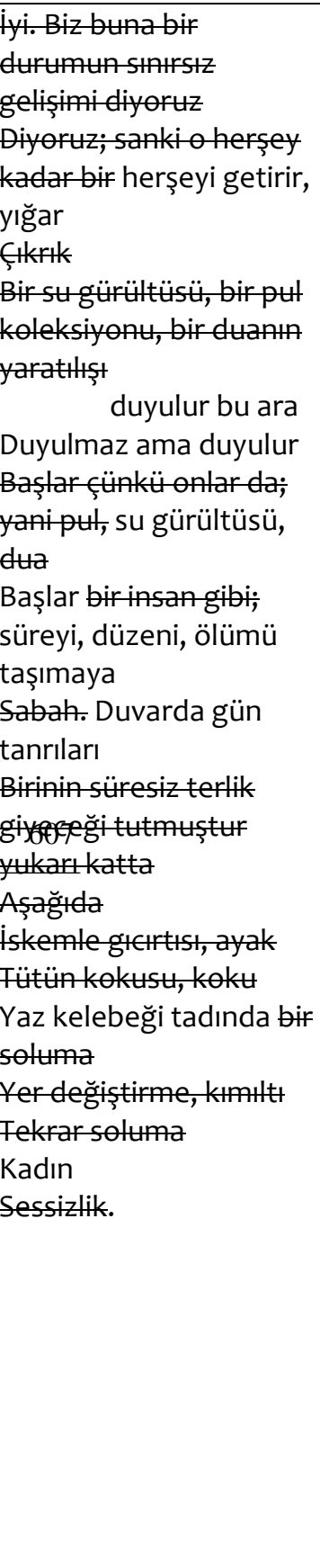 & 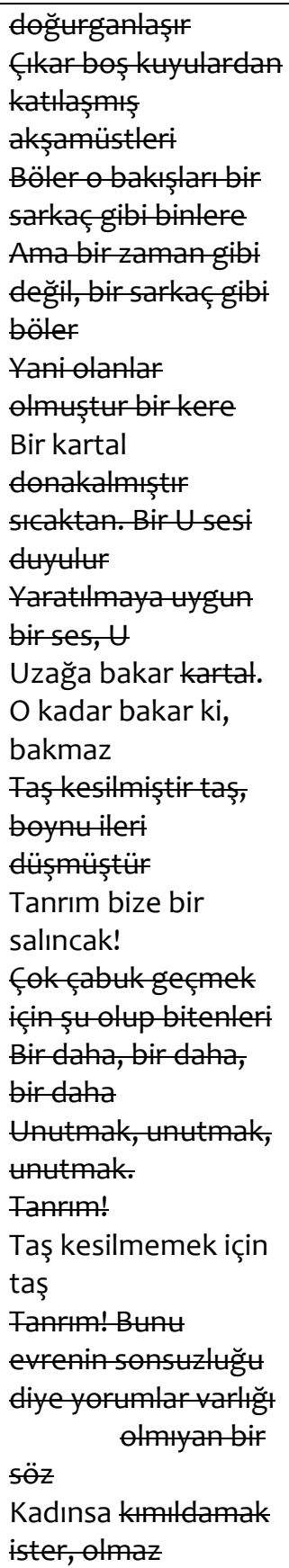 & 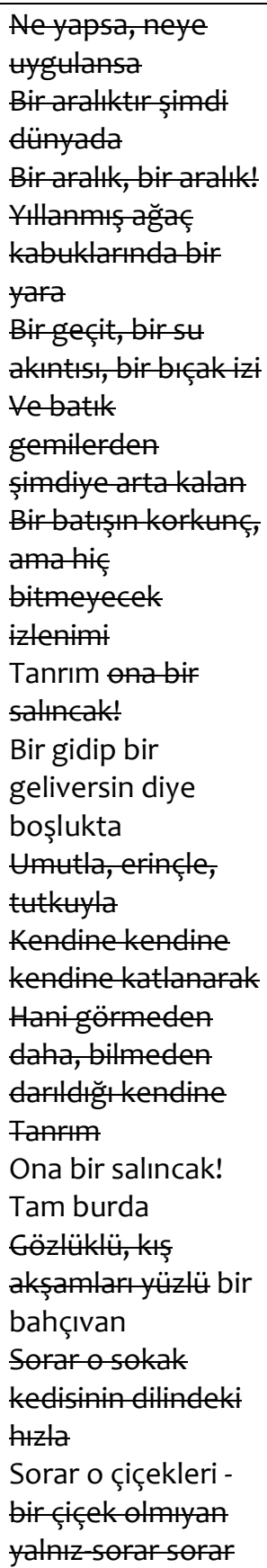 & 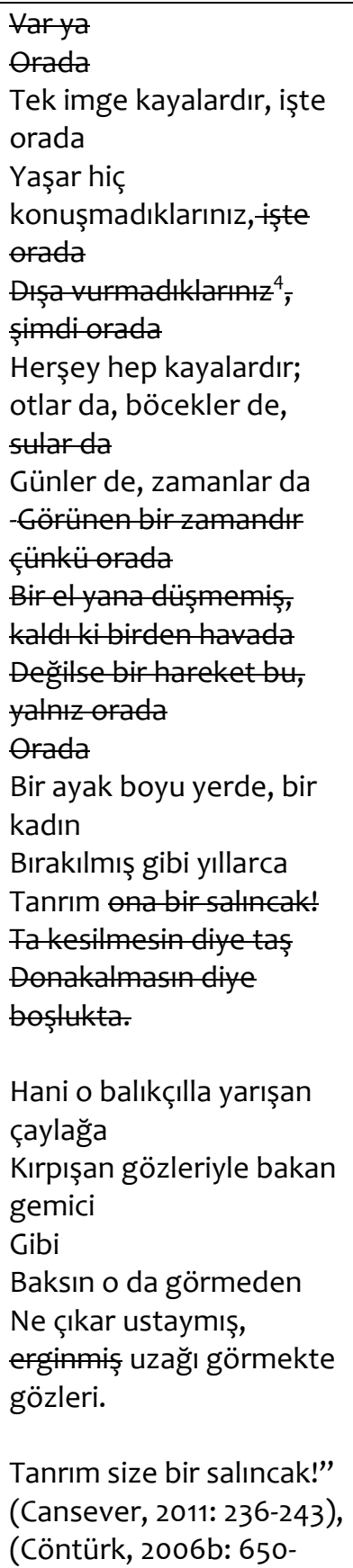 \\
\hline
\end{tabular}

\footnotetext{
${ }^{4}$ Cöntürk'te dışa vurduklarınız şeklinde geçmektedir. bk. Cöntürk, Hüseyin (2006b). Çağının Eleştirisi (ikinci Kitap). İstanbul: Yapı Kredi, s. 653.
} 


\begin{tabular}{|c|c|c|c|}
\hline & $\begin{array}{l}\text { Yer değiştirmek } \\
\text { ister, olmaz } \\
\text { Solumak birdenbire } \\
\text { Gene olmaz } \\
\text { Olacak birşey } \\
\text { boşuna aranır, } \\
\text { boşuna boşuna } \\
\text { boşuna } \\
\text { Bir kaya daha-çatlar } \\
\text { Başlar ufacık taşlar } \\
\text { yuvarlanmayya } \\
\text { Eser bir silinti, bir } \\
\text { sisin dağıllışındaki öz } \\
\text { Ȩıar o yunus balığı, } \\
\text { o heykel } \\
\text { łaz kelebeği, kapt } \\
\text { Sonra? }\end{array}$ & 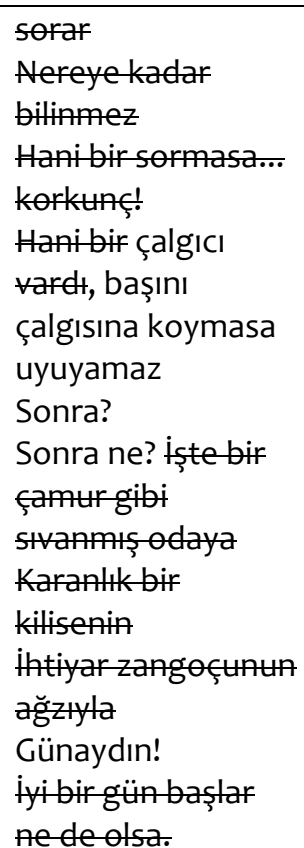 & 653) \\
\hline
\end{tabular}

Görüldüğü gibi Cöntürk'ün, Cansever'in şiiri üzerindeki müdahalesinin temelini üzerini çizerek çıkarmak oluşturur. Öyle ki Cöntürk, yedi yüz iki sözcükten oluşan ${ }^{5}$ tartışma konusu şiirden beş yüz altı sözcüğün üstünü çizmiştir. Bu durumda Cöntürk, şiirin neredeyse dörtte üçünü çıkarmış olur. Hâl böyleyken Cöntürk'ün ele alınan şairin Tragedyalar adlı kitabıyla ilgili yazdığı yazıda Tragedyalar kitabının "Salıncak" şiirinin altında kaldığını söyler ve bunun nedenini ise onun yoğun olmasına bağlar. Cöntürk'e göre Tragedyalar, dörtte bire indirilebilirdi: “'Salıncak' doruğunun çok altında kalmış. Yoğun değil, dörtte bire indirilebilirdi. Indirilseydi belki yeni bir doruk olurdu." (2006: 439). Ancak bu ifadelerine karşılık Cöntürk'ün yoğun bulduğu "Salıncak" şiirini neredeyse dörtte bire indirmesi dikkat çekicidir. Bu noktada Cöntürk'ün "Salıncak" şiiri üzerindeki müdahalelerinin anlamı tartışılabilir.

Cansever'in "Salıncak" şiirinde, birçok şiirinde olduğu gibi yalnızlık, tekdüzelik, sıkıntı/ağrı, anlamsızlık duygusuyla gelişen anlam arayışı gibi varoluşsal izlekler görülür. Bahsedilen varoluşsal sıkıntı ve yalnızlık daha ilk mısralardan itibaren şiirde görünür olmaya başlar. Şiirin ilk bölümündeki ayrıntılı tasvir, Cöntürk'ün de tespit ettiği gibi, kesik kesiktir ve şiirin içeriğiyle doğrudan ilişkilidir (2006a: 393). Ancak düzyazıda sıklıkla karşılaşılan ayrıntılı mekân

\footnotetext{
${ }^{5}$ Buradaki hesaplamada ayrı yazılan her unsur sözcük olarak kabul edilmiş, öte yandan bitişik yazılan "herşey” gibi ifadeler tek bir sözcük olarak hesaplanmıştır.
} 
tasvirini Cöntürk çıkarır ve bunun yerine "yunus balığı heykeli" ve "çıkrık" metaforlarını ön plana çıkarır. Ayrıca "Yani hiçbir şey yerinde değil pek.", "Biz buna bir durumun sınırsız gelişimi diyoruz", "Başlar çünkü onlar da" gibi düzyazıya özgü ve açıklamaya dayalı mısraları da çıkarır. Şiirin yalnızca ilk bölümünde yirmi kez "bir” ibaresi kullanılmıştır ki bu durum şiir için bir ağırlık teşkil etmektedir. Cöntürk, diğer taraftan ilk bölümü "sessizlik" yerine "kadın" sözcüğü ile bitirir. Böylelikle şiirde ileride çok daha anlamlı bir hâle gelecek kadın figürünü okurla erken tanıştırır.

Cöntürk, "Salıncak" şiirinin ikinci kısmında ruh hâlinin daha çok duygu açısından verildiği görüşündedir (2006a: 398). Ona göre varsayılan kertenkelenin yapıp ettikleri, uzağa bakıp taş kesilen kartal imgesi okurda "eşbenzeti” yoluyla ruhsal empati kurmaya yarar (2006a: 398). Cöntürk, şiirdeki bu tekniği muhafaza etse de mısraları kısaltıp yalınlaştırır ve onların yoğunluklarını artırmaya çalışır. Mısralar, içerikle uyumlu olarak kesik ve kısa bir şekilde kurulur. Ancak şiirin akıcılığı bu şekilde zarar görür. Cöntürk ikinci bölümde ilk bölümde öne çıkardığı yunus balığı heykelini tekrar vurgular. Ancak burada esas ön planda olan figür, “yokluğu sağan kadın”dır. Cöntürk, şiirde "yokluğun sağılması” sözünün iki kez geçmesinin "itnabı aşarak” şiiri zenginleştirdiğini dile getirir (2006a: 399). Ancak bu görüşünden sonradan vazgeçmiş olacak ki "yokluğu sağmak” ifadesini teke indirir.

"Yokluğu sağan kadın” figürü, şiirdeki varoluşsal anlam arayışı ve sıkıntı kavramıyla uyumlu bir hâldedir. Ancak Cöntürk'ün, Cansever'in kadına yönelik birçok açımlayıcı ifadesini eksilttiği de gözlemlenmektedir:

Diyoruz; çünkü o, kadın

Ne yapsa, neye uygulansa

Bir aralıktır şimdi dünyada

Bir aralık, bir aralık!

Yıllanmış ağaç kabuklarında bir yara

Bir geçit, bir su akıntısı, bir bıçak izi

Ve batık gemilerden şimdiye arta kalan

Bir batışın korkunç, ama hiç bitmeyecek izlenimi (Cöntürk, 2006b: 652)

Cansever, kadının dünyada bir aralık olma durumunu üç kez tekrarlayarak vurgular ve daha sonraki ifadelerinin hepsi kadının bahsedilen özelliğini tamamlayıcı bir niteliktedir. Cöntürk, bunu bir defa dile getirmenin yeteceğini düşünür. "Ağaç kabuğunda yara”, "bir geçit”, "batık gemilerden arta kalan” gibi ifadeler bahsedilen imgeyi zenginleştirmek yerine çoğaltan bir niteliktedir. 
Cöntürk, şiirde beğendiğini belirttiği (2006a: 400-401) gül çukurunun tersine dönmesi ve kadının bir aralık gibi durması imgelerini şiirde sürmesi isteğindedir. Aynı şekilde beğendiği "o kadar bakar ki bakmaz" ifadesini de şiirde korur. Cöntürk, "Salıncak" şiiriyle ilgili yazdığı yazıda "Kartalla birlikte bütün evren enstantane hali içinde ölümleşiyor." (2006a: 400) der. Kartalın bakmaz hâle gelişiyle kadının bir aralık gibi dünyada durması birbirini zenginleştirir. Her şey o kadar durgundur ki kadın elinde tuttuğu kitabı okumaz. Bu kadar durağan bir şekilde dünyada yer alan varlıkları harekete geçirecek tek nesne "salıncak" metaforudur. Birçok çağrışımsal zenginliğe sahip salıncak metaforunun özellikle hareket kabiliyeti ile şiirde işlevsel bir değere sahip olduğu vurgulanmalıdır. Aynı zamanda salıncak, aralıkta duran kadının iki farklı tarafa gidip gelmesine de yarayacaktır.

Cöntürk, Cansever'in "Salıncak" şiirinde kilit önemde olduğunu düşündüğü metaforları ön plana çıkarmaya uğraşırken bahsedildiği gibi fazlalık bulduğu imge ve metaforları eksiltme eğilimindedir. Bununla birlikte açıklayıcı ifadeleri özellikle çıkarma eğilimindedir. "Görünen bir zamandır çünkü orada" ve "Taş kesilmesin diye taş" gibi ifadelerin üstünün çizilmesi gerektiğini düşünür. Cöntürk için gündelik dile yaslanan mısraların da çıkarılması gerekmektedir. Bunları yaparken şiirin kilit kısımlarına çağrışım güçlerini artırarak şiirde yer vermek ister. Böylelikle şiiri kendi ifadesiyle “yoğun” kılmaya çalışır.

Cöntürk'ün, Cansever'in şiirine müdahalelerinin temelinde saf ve lirik şiir anlayışı bulunmaktadır. Bu doğrultuda en az kelime ile çoğul anlama ulaşma, şiir dili ile gündelik dili ayırma, şiirde ahengi ön planda tutma vb. çabalar etkilidir. Ancak Cöntürk, benimsediği poetik anlayış doğrultusunda "Salıncak" şiirini yeniden yazarken Cansever'in şiirde yapmaya çalıştıklarını ortadan kaldırır. Cansever, bilinçli olarak şiiri düzyazılaştırmaya çalışır ve çok belirgin bir şekilde şiirde çok sesliliği hâkim kılmak için uğraş verir (Tunç, 2010: 100-101).

Burada şu soru sorulabilir: Cöntürk'ün yapıp ettiklerini nasıl anlamlandırmak gerekir? Cöntürk, "[Hiperteks Üzerine Notlar]” adlı yazısının 21. Notunda hipertextlerin yapılma gerekçesini ve onların niteliğini şöyle sınıflandırır:

1) Eleştirel: a) şairin bir temasını açıklayan (Ş. Kurdakul) b) iyi olmayan şairlerin adını tescil 2) Şairi temsil: a) şairin bir temasını temsil; şair yerine şiir yazma b) şairden daha iyisini kendi malzemesiyle yazmaya çalışmak 3) Şairi yermek için: a) yermek, dolaylı kötülemek b) alay etmek 4) Genel (okuyucu için): a) okuyucuyu şiir/şair bolluğundan kurtarıp “öz”le tanıştırmak (kitaptan uzaklaştırmak) b) yeni bağlamlar yaratarak şiire zenginlik yenilik kazandırmak. (2006b: 644)

Cöntürk'ün hipertext yazma uğraşının görünür nedenlerinden biri "şairden daha iyisini" kendi malzemesiyle yazma çabasıdır. Ancak bu nedeni biraz daha sorguladığımızda, altında bir eleştirmen tavrıyla karşılaşırız. Cöntürk, bahsedilen yazısının 39. notunda "Bir şiir kitabını eleştirmektense o kitaptaki 
başlıca temaların hipertekslerini yapmayı tercih edebiliriz (Eleştirme yerine şiir ikamesi)." (2006b: 647) düşüncesini ileri sürer. Söz konusu sav, tam da Cöntürk'ün Cansever'in "Salıncak" şiirine müdahalesini anlamlandırmak açısından çok işlevsel değerdedir. Çünkü Cöntürk birçok yazısında daha önce bahsedildiği gibi, Cansever'in şiirlerinde genel olarak gereksiz sözcük ve mısra kullanımına değinir. Ayrıca Cansever'in şiirlerinden eksiltme yapıldığında şiirlerden bir şey eksilmeyeceğini öne sürer. Bu çerçevede Cöntürk'ün hiperteks uygulaması, kendi ifadesiyle koşut olarak, "eleştirme yerine şiir ikamesi” işlevine sahiptir. Ancak buradaki çelişkili nokta, Cöntürk'ün, Cansever'in doruk şiiri olarak konumlandırdığı "Salıncak" şiiri üzerinden hiperteks uygulamasını (bir başka şekilde palimpsestteki ikinci yazı) gerçekleştirmesidir. Cöntürk, hipertext niteliğindeki eleştirilerin okuru "daha az riskle kendi değerlendirmelerini" hipertexte ekleme imkânı sağladığından söz eder. Ona göre hipertext bu durumuyla klasik eleştiriyi işlevden düşürmüştür (2006b: 646). Bu tarz bir eleştiri, geleneksel eleştirinin ve buyurucu eleştirmenin aksine aktif okuru öngörür. Cöntürk de bu çaba içindedir. Diğer taraftan hipertext bir oyundur, bu oyun sayesinde kendi bağlamında hapsolmuş şair için sayısız bağlam yaratılır (2006b: 647). Bir başka ifadeyle eleştirmen gözüyle Cöntürk, şaire ve okura yeni yorum imkânları sunmak ister.

\section{Hayriye Ünal'ın Cahit Zarifoğlu'nun “Başım Eğik Dilim Kapalı Gözler Kançanağı Anlamında" Şiirini Yeniden Yazımı}

Cöntürk'ün Cansever'in “Salıncak” şiirindeki bazı kısımların üstünü çizmesi ve böylelikle onu hipertext olarak yeniden yazması iki yazının bütünlüğü bağlamında palimpsest olarak değerlendirilmiștir. Ayrıca Cöntürk'ün yeniden yazımının temelinde eleştirmen tavrının baskın olduğu vurgulanmıştır. Görünüşte benzer bir uygulamaya Hayriye Ünal'da da rastlanmaktadır. Ünal, Cahit Zarifoğlu'nun bilinen “Başım Eğik Dilim Kapalı Gözler Kançanağı Anlamında” şiirini hipotext (ilk metin) olarak kullanır ve bir hipertext (üst metin) gerçekleştirir. Ancak bahsedilen ilk ve ikinci metin arasındaki palimpsest ilişkisinin Cöntürk ve Cansever'in metinleri arasındaki ilişkiden temel farklılıklar gösterdiğinin altı çizilmelidir. Iffade edilen farklılığın en önemli tarafı ise içerikte aranmalıdır. Zarifoğlu'nun ilk metin olarak kullanılan şiiri şöyledir:

\begin{tabular}{|l|l|l|}
\hline “Asrımızın zarif & Hayır dokuzyüz & Sen dinçzaman \\
düşünceli gençlerinden & Ailyon müslüman & İşte kuluçkan \\
biri & Tarihin hülyalarından & Bereketle taşan yağ \\
Kederli elini & vazgeçmiş olabilir AMA & küpleri gibi \\
Temiz alnına koyarken & BEN & Parmaklardan akan \\
fikretmek için & Elim dizlerime Vur Kalk & çeşmeler gibi \\
Çocukların susması & Müslümanlar uyanm Eller & \\
\hline
\end{tabular}




\begin{tabular}{|c|c|c|}
\hline 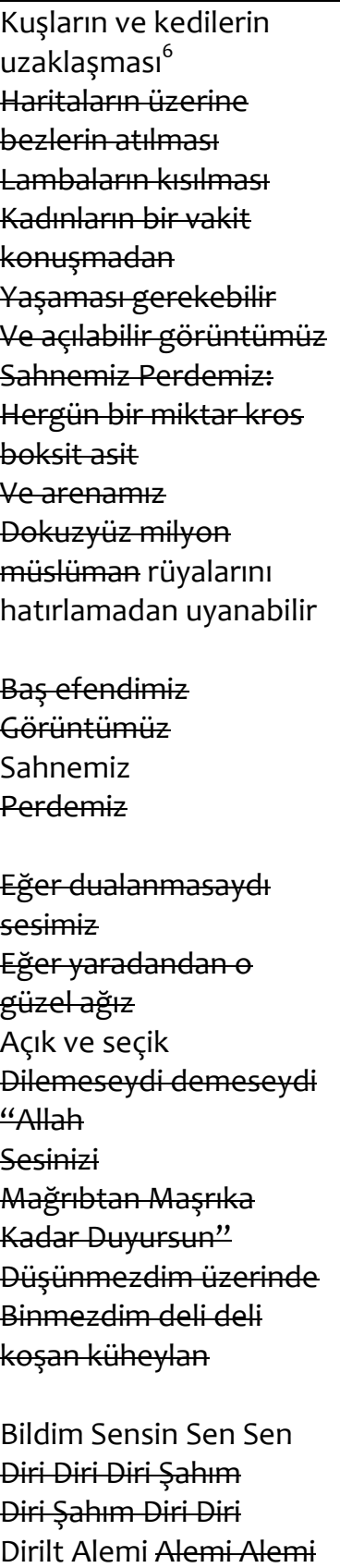 & 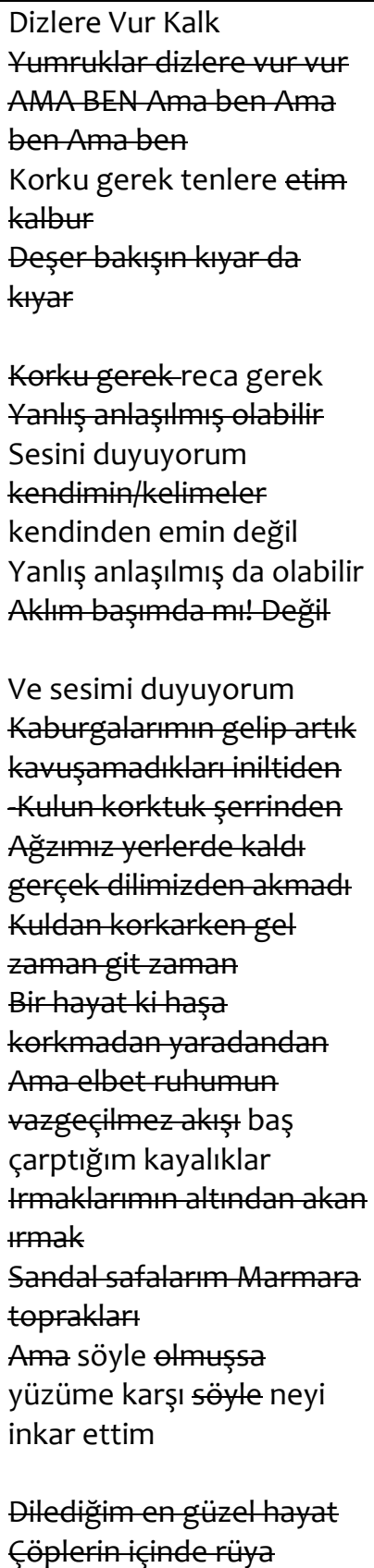 & 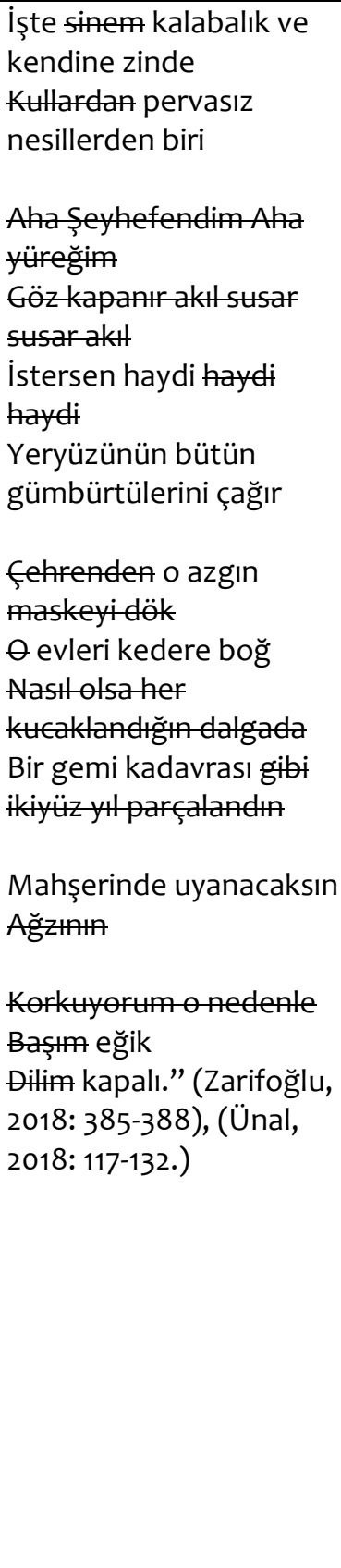 \\
\hline
\end{tabular}

\footnotetext{
${ }^{6}$ Ünal'ın kitabında şiirin “Kederli elini / Temiz alnına koyarken fikretmek için / Çocukların susması / Kuşların ve kedilerin uzaklaşması” mısraları yer almamaktadır. Bk. Ünal'ın metninde hipotekst olarak geçer. Bk. Ünal, H. (2018). Yüz Sene Daha. Ankara: Hece, s. 127.
} 


\begin{tabular}{|c|c|}
\hline $\begin{array}{l}\text { Alemi } \\
\text { Çünkü dokuzyüz milyon } \\
\text { müslüman rüyalarını } \\
\text { hatırlamadan uyanmıştır } \\
\text { Bunların üzerine ezan } \\
\text { Ueu sancılar vuran } \\
\text { Bir kırbaç olmalıydı } \\
\text { Her duyan } \\
\text { Bağrını açmalıydı akan } \\
\text { kanı da sevdayı da } \\
\text { yorumlamaya almalıydı }\end{array}$ & $\begin{array}{l}\text { aradım } \\
\text { Düştümse eğer sana } \\
\text { bakarken düştüm }\end{array}$ \\
\hline
\end{tabular}

Ünal'ın Zarifoğlu'nun şiirine müdahalesinin temelini, Cöntürk'te olduğu gibi, sözcük çıkarımı oluşturmaktadır. Ünal, üç yüz yirmi yedi sözcükten oluşan ${ }^{7}$ şiirden iki yüz yirmi dört sözcüğün üstünü çizmiş, çıkarmıştır. Böylelikle Ünal, ilk metnin üçte ikisinden fazlasını çıkarmış olur. Bu aşamada söz konusu müdahalelere odaklanarak bunların anlamının ne olduğu sorgulanabilir.

Zarifoğlu'nun bahis konusu şiirinde baskın olan unsur İslami duyarlılıktır. Bu çerçevede kendini çağından sorumlu hisseden şair (Ünal, 2014: 249), modern zamanları eleştirmekte, kuldan korkulup yaratandan korkulmadığı zamanlardan Müslümanların uyanmaları gerektiğini dile getirmektedir. Şiiri kişileştirerek onun da tıpkı insan gibi “yaratan”a doğru bir yönelme içerisinde bulunduğuna inanan Zarifoğlu'nun (Daşçıoğlu, 2008: 29) tartışma konusu şiiri de aynı poetik anlayış doğrultusunda kaleme aldığı görülmektedir. Bu şiirde Zarifoğlu için önemli olan (ilk dönemde saf şiir poetikası doğrultusunda yazdığı şiirlerin aksine) şiirin toplumsal işlevidir. Şiirde konu edinildiği gibi söylersek şiirin işlevi toplumu (burada Müslümanları) uyandırmaktır. Korku ve yakarışın hâkim olduğu şiirde baştan sona Allah, kul, ezan, Müslüman, mahşer gibi İslami literatüre ait sözcüklerin kullanılması şiirin şaire göre ereği ile ilgilidir. Şiirin yapısı da toplumsal içeriği somutlama işlevi taşır. Şiirdeki bazı sözcüklerin bütün harflerinin büyük yazılması (AMA BEN gibi) vurgulanmaya çalışılan içeriği ön planı çıkarır. Yakarışı baskın kılmaya çalışan şair, ahengi yakalamak için “sözcük ekonomisini” göz ardı ederek sözcükleri gerektiğinden fazla kullanmaktan çekinmez:

Müslümanlar uyanın Eller Dizlere Vur Kalk

Yumruklar dizlere vur vur

AMA BEN Ama ben Ama ben Ama ben

\footnotetext{
${ }^{7}$ Buradaki hesaplamada ayrı yazılan her unsur sözcük olarak kabul edilmiștir.
} 
Korku gerek tenlere etim kalbur

Deşer bakışın kıyar da kıyar. (Zarifoğlu, 2018: 386)

“Başım Eğik Dilim Kapalı Gözler Kançanağı Anlamında” şiirinde şair kendi özelinde Müslümanların durumunu sorgular. Onların uyanması çağrısında bulunur. Bununla birlikte şairin yakarışta bulunduğu varlığın sorgulanması da şiirin anlaşılması için işlevsel önemdedir. Bahis konusu şiirde sevgi ve itaatle seslenilen, yakarıșta bulunulan varlık, şiirin farklı yerlerinde Allah, Hz. Peygamber ve mürşidi olan, yazılarında "Efendimiz" hitabıyla seslendiği Abdurrahim Reyhan Efendi gibi değişik boyutlarda yorumlanabilecek özelliklere sahiptir.

Görüldüğü gibi Zarifoğlu'nun “Başım Eğik Dilim Kapalı Gözler Kançanağı Anlamında” şiiri ilk okuyuşta bile kendisini ele verecek bir şekilde İslami bir anlayışa sahiptir. Hayriye Ünal'ın, hipotext olarak seçtiği bu şiire dair müdahaleleri bilhassa İslami içeriği oluşturan sözcüklerin çıkarılmasına yöneliktir. Örneğin Zarifoğlu'nun “Çünkü dokuz yüz milyon müslüman rüyalarını hatırlamadan uyanmıştır." mısrasındaki "Müslüman” sözcüğünü çıkarmış ve hatırlama edimini genelleştirmiştir.

Ünal'ın hipertext uygulamasında dikkat çeken bir diğer özellik, Zarifoğlu'nun konu edilen şiirindeki uzun, zaman zaman okumayı zorlaştıran mısraları kısaltması ve onları daha akışkan kılmasıdır. Örneğin Zarifoğlu'nun

Ve sesimi duyuyorum

Kaburgalarımın gelip artık kavuşamadıkları iniltiden

-Kulun korktuk şerrinden

Ağzımız yerlerde kaldı gerçek dilimizden akmadı

Kuldan korkarken gel zaman git zaman

Bir hayat ki haşa korkmadan yaradandan

Ama elbet ruhumun vazgeçilmez akışı baş çarptığım kayalıklar

Irmaklarımın altından akan ırmak

Sandal safalarım Marmara toprakları

Ama söyle olmuşsa yüzüme karşı söyle neyi inkar ettim. (Zarifoğlu, 2018: 387)

mısralarındaki birçok sözcüğün üstünü çizerek şiiri yeniden yazar. Bu durum tıpkı palimpsestlerde olduğu gibi ilk yazının kazınması ile oluşturulmuştur. Ancak buradaki fark, ilk yazının üstü silindikten sonra yeni bir yazı yazılma gereksinimi duyulmamasıdır; çünkü ilk yazıdaki bazı sözcüklerin üstü çizildiğinde 
ortaya bambaşka bir yazı çıkmıştır. Ünal'ın müdahalesi sonucunda üstteki mısraların son hâli şöyle olmuştur:

\author{
Ve sesimi duyuyorum \\ baş çarptığım kayalıklar \\ söyle yüzüme karşı neyi inkar ettim. (Ünal, 2018: 134)
}

Ünal, Zarifoğlu'nun şiirde içeriği güçlendirmek adına yaptığı tekrarları da azaltma gayreti içine girmiştir. Örneğin Zarifoğlu'nun şiirindeki “Diri Diri Diri Şahım / Diri Şahım Diri Diri /Dirilt Alemi Alemi Alemi Alemi”-mısralarında yer alan tekrar sözcüklerin üstünü çizer. Her ne kadar şiirsel müdahalelerin örnekleri artırılabilecek olsa da Ünal'ın, Zarifoğlu'nun “Başım Eğik Dilim Kapalı Gözler Kançanağı Anlamında” şiirini neden hipotext olarak ele aldığı ve bu şiire hipertext yazarak neden palimpsestvari bir ilişki içine girdiği sorusu sorulabilir.

Ünal, “Zarifoğlu Şiirine 'Stad' Odaklı Bir Bakış” adlı yazısında, Zarifoğlu'nun şiirlerinin yer yer zayıflayıp yer yer çok güçlendiğinden bahseder. Ona göre Zarifoğlu'nun şiirlerinde doruğa ulaşan bölümlerin dışında kalan yerler daha çok anlatılmak istenen fikre hizmet eder ve sadece işlevsel olarak şiire sokulmaktan ötürü düzyazıya yaklaşırlar (2014: 243). Ünal'ın bahsedilen düşünceleri esas alındığında Zarifoğlu'nun şiirine müdahalesinin bu zayıf yerleri çıkarma amacı taşıdığı varsayılabilir. Bu varsayıma göre Ünal, Zarifoğlu'nun şiirindeki zayıf bölümlerin üstünü çizerek ayıklamış ve çok güçlü yerleri muhafaza etmiştir. Eğer bu varsayımı kabul edersek Ünal'ın tavrıyla Cöntürk'ün yaptıkları arasında bir koşutluk ilişkisi kurulabilir. Ancak Ünal'ın şair kimliği de bu noktada göz önünde bulundurularak hipertext girişimine farklı bir açıdan yaklaşmak mümkündür.

Ünal yazdığı hipertextin hemen altına yaptığının ne anlama geldiği konusunda okura ipucu verecek şekilde açıklamalarda bulunur. Söz konusu açıklama ise hipertextin ne olduğu kadar onun neden yapıldığını da ortaya koyar:

[Hipertext] $]^{8}$ bir biçimsel dönüştürüm işlemidir. Bağlantılı metin üretmece oyunu olarak da tanımlanabilir. Bir metni ikiye ayırmak veya eksilterek dönüştürmek çok sayıda olasılığa bağlıdır. Eleştirel bir bakışla yapılabileceği gibi bir saygı ifadesi olarak da yapılabilir. Her okuyucu bir metni okurken bilinçli ya da bilinçsiz çeşitli eksiltmeler yapar. (Ünal, 2018: 127)

Ünal, alıntıda görüldüğü gibi, hipertextin yapılmasını iki muhtemel nedene bağlar. Bunlar eleştiri ve saygıdır. Eğer Ünal'ın şiire müdahalesini zayıf noktaları ayıklamak olarak anlamlandıracaksak burada saygıdan çok bir

\footnotetext{
${ }^{8}$ Ünal'ın metninde hipotekst olarak geçer. Bk. Ünal, H. (2018). Yüz Sene Daha. Ankara: Hece, s. 127.
} 
eleştiriden söz etmek yerinde olacaktır. Ancak Ünal, Zarifoğlu'nun şiirine müdahalesinden sonra söz konusu şiir bambaşka bir niteliğe sahip olmuştur. Bir başka ifadeyle Ünal, bir şair olarak Zarifoğlu'nun “Başım Eğik Dilim Kapalı Gözler Kançanağı Anlamında" şiirindeki bazı sözcükleri çıkararak bu şiiri kendi poetikasına yaklaştırmayı başarmıştır. Hatırlanacağı gibi Zarifoğlu şiirinde modern zamanları eleștirmiş ve Müslümanların kötü bir rüyadan uyanmasını, ayağa kalkmasını dilemiştir. Fikir yönü baskın olan şiirde beșeri duygular değil ilahi duygular hâkimdir. Buna karşılık Ünal, sadece sözcükleri çıkararak şiirin içeriğini bambaşka bir düzleme taşır. Saçları Vardır Aşkın ve Şimdi Aşk Ebediyyen Değişir kitaplarının yazarı olan şair, şiirde beșeri aşktan bahseder. Zarifoğlu'nun şiirinde Müslümanları temsil eden "zarif düşünceli genç”, Ünal'ın şiirinde beşeri aşkın temsiline dönüşür. Zarifoğlu'nun dinsel yakarışı Ünal'da yerini sevgiliye yakarışa bırakmıştır:

Korku gerek tenlere

reca gerek

Sesini duyuyorum kendinden emin değil

Yanlış anlaşılmış da olabilir

Ve sesimi duyuyorum

baş çarptığım kayalıklar

söyle yüzüme karşı neyi inkar ettim

Düştümse eğer sana bakarken düştüm. (Ünal, 2018: 134)

Bu aşamada şu sav öne sürülebilir: Ünal'ın sadece sözcük çıkararak Zarifoğlu'nun şiirini kendi şiirlerine eklemleyebilmesi hipertextin bir başka özelliği olan estetiksel meydan okumaya tekabül eder. Ünal, şiirlerine saygı duyduğu Zarifoğlu'nun şiirini temel alarak sadece sözcük çıkararak onun şiirini kendi poetikasına eklemleyebileceğini göstermiștir. Ayrıca Zarifoğlu ve Ünal'ın şiirleri bir sayfada, palimpsest olarak birbirlerini zenginleştiren özelliğe sahip olmuştur.

\section{Sonuç}

Bir şiir yayımlandıktan sonra ona herhangi bir müdahalede bulunulmaması düșüncesi birçok kişinin hemfikir olduğu bir niteliktedir. Bilhassa saf şiir düşüncesini benimseyen şairler, tamamlanmış iyi bir şiire yapılacak en ufak müdahalenin onun hüviyetini ortadan kaldıracağı kanaatindedirler. Ancak birçok şair, bazen şiirsel tahakküm kurma endişesi bazen de dostça öneri amacıyla başkalarının tamamlanmış şiirlerine müdahale etme gayretine girerler. Türk edebiyat tarihinde başkalarının şiirlerine müdahale eden birçok önemli şair örneği bulunmasına karşılık bu makalede hipertext kavramı temelinde başka bir şairin 
şiirine, onun şiirindeki sözcüklerin üstünün çizilmesi suretiyle müdahalede bulunulması konu edinilmiştir. Söz konusu çerçevede modern eleştirinin önemli ismi Hüseyin Cöntürk ile yaşayan Türk şiirinde deneysel şiirleri ile dikkat çeken Hayriye Ünal'ın hipertext uygulamaları örneklem olarak sorunsallaştıııımıştır. Buna göre Cöntürk'ün Cansever'in "Salıncak"; Ünal'ın Zarifoğlu'nun “Başım Eğik Dilim Kapalı Gözler Kançanağı Anlamında" şiirini hipotext olarak seçmeleri ve bu hipotext üzerinden kendi şiir algılayışları doğrultusunda onları yeniden yazmaları tartışıımışıı. Hipotext ve hipertextlerin aynı yüzeyde bulunmalarından yola çıkarak palimpsest kavramına makalede yer verilmiştir. Böylelikle hipotextle hipertext arasındaki alışverişe dikkat çekilmiştir. Makalede incelenen metinlerden yola çıkarak yapılan hipertextlerin içeriğiyle ilgili varılan sonuç şudur: Cöntürk, bir eleştirmen olarak birçok farklı yazısında Cansever'in şiirinde birçok gereksiz sözcük kullanımının olduğunu öne sürer. Bu yolda Cöntürk'ün hiperteks uygulaması, kendi ifadeleriyle koşut olarak, "eleştirme yerine şiir ikamesi" işlevine sahiptir. Ancak Cöntürk'ün, Cansever'in doruk şiiri olarak konumlandırdığı "Salıncak" şiiri üzerinden hiperteks uygulamasını (bir başka şekilde palimpsestteki ikinci yazı) gerçekleştirmesinin çelişkili olduğuna işaret edilmiştir. Cöntürk, bu çabasıyla klasik eleştiriye alternatif olarak okuru daha etkin kılan bir eleştiri anlayışı geliştirmeye çalışır. Öte yandan bir şair olarak Ünal'ın Zarifoğlu'nun şiirini hipotext olarak seçmesinin altında bir iddia yatar. Ünal'ın Zarifoğlu'nun şiirini seçmesi her ne kadar saygı boyutu içerse de Ünal, şairden daha iyisini kendi malzemesiyle yazma gayretindedir. Böylelikle Ünal, selefi olan Zarifoğlu'na karşı estetik bir meydan okuma çabasındadır. Zarifoğlu'nun İslami içeriğe sahip, "hakiki aşkı" dile getiren şiirini sadece kelimelerini çıkararak dönüştürmüş, kendi şiirleri çizgisine taşımıştır. Ünal'ın hipertextinde aşk dünyevileşmiş ve şairin daha önceki şiirlerindeki anlama dönüşmüştür.

\section{Kaynakça}

Ahmet Haşim (1999). Bütün Şiirleri: Piyale/Göl Saatleri/Diğer Şiirleri. Haz. İnci Enginün-Zeynep Kerman. İstanbul: Dergâh.

Aktulum, K. (2000). Metinlerarası Iliş̧kiler. Ankara: Öteki.

Ayda, A. (1962). Yahya Kemal: Kendi Ağzından Fikirleri ve San'at Görüşleri. Ankara: Ajans-Türk Matbaası.

Baldick, C. (2001). The Concise Oxford Dictionary of Literary Terms. New York: Oxford University Press.

Beyatl, Y. K. (1997). Edebiyata Dair. İstanbul: İstanbul Fetih Cemiyeti.

Bezirci, A. (1961). Edip Cansever. İstanbul: De.

Borges, J. L. (2014). Ficciones: Hayaller ve Hikâyeler. Tomris Uyar-Fatih Özgüven (Çev.). İstanbul: iletişim.

Cansever, E. (2011). Sonrası Kalır (Bütün Şiirleri 1). İstanbul: Yapı Kredi. Cöntürk, H. (2006a). Çağııın Eleştirisi (Birinci Kitap). İstanbul: Yapı Kredi. Cöntürk, H. (2006b). Çağının Eleştirisi (ikinci Kitap). İstanbul: Yapı Kredi. 
Daşçıŏlu, Y. (2008). Kader Hep Erken Zaman Hep Geç Cahit Zarifoğlu'nun Şiirleri. istanbul: $3 \mathrm{~F}$.

Dillion, S. (2017). Palimpsest: Edebiyat, Eleștiri, Kuram. Ferit Burak Aydar (Çev.). İstanbul: Koç Üniversitesi.

Eyuboğlu, S. (1981). Sanat Üzerine Denemeler ve Eleştiriler. İstanbul: Cem.

Kavaz, i. (1989). “Necip Fazıl Kısakürek'in Şiiri ve Şiirlerindeki Değişmeler Üzerine". FIrat Üniversitesi Sosyal Bilimler Dergisi 3 (2), 201-223.

Necatigil, B. (2001). Mektuplar. İstanbul: Yapı Kredi.

Necatigil, B. (2012). Bile/Yazdı. İstanbul: Yapı Kredi.

Tanpınar, A. H. (1995). Yahya Kemal. İstanbul: Dergâh.

Tanpınar, A. H. (1997). Edebiyat Üzerine Makaleler. İstanbul: Dergâh.

Tanpınar, A. H. (2000). Yaşadığım Gibi. İstanbul: Dergâh.

Tunç, G. (Mayıs 2010). Türk Edebiyatında Şiir ve Düzyazı Romanın Sınırları. Hece 162, 99-103.

Uysal, S. S. (1959). Yahya Kemal'le Sohbetler. İstanbul: Kitap.

Uysal, S. S. (2009). 125. Doğum Yılında Değişik Yanlarıyla Yahya Kemal. İstanbul: Bilge Kültür Sanat.

Ünal, H. (2014), Tahlil Tahrip inşa. Ankara: Hece.

Ünal, H. (2018), Yüz Sene Daha. Ankara: Hece.

Zarifoğlu, C. (2018). Şiirler. İstanbul: Beyan. 